\title{
К.Ю. Гашинова
}

\author{
ХРОНІЧНЕ ОБСТРУКТИВНЕ \\ ЗАХВОРЮВАННЯ ЛЕГЕНЬ (ХОЗЛ): \\ ВПЛИВ КЛІНІКО-АНАМНЕСТИЧНИХ, \\ АНТРОПОМЕТРИЧНИХ \\ ТА ФУНКЦІОНАЛЬНИХ ХАРАКТЕРИСТИК \\ НА РІВЕНЬ А-1-АНТИТРИПСИНУ (ААТ) \\ В СИРОВАТЦІ КРОВІ СТАБІЛЬНИХ ХВОРИХ
}

\author{
Д3 «Дніпропетровська медична академія МОЗ України» \\ кафедра професійних хвороб та клінічної імунології \\ (зав. - д. мед. н. дочент К.Ю. Гачинова) \\ вул. В. Вернадського, 9, Дніпро, 49044, Украӥна \\ $S E$ «Dnipropetrovsk medical academy of Health Ministry of Ukraine» \\ Department of occupational diseases and clinical immunology \\ V. Vernadsky str., 9, Dnipro, 49044, Ukraine \\ e-mail: gashynova@gmail.com
}

Ключові слова: ХОЗЛ, загострення, $\alpha$-1-антитрипсин Ключевые слова: ХОБЛ, обострение, $\alpha$-1-антитрипсин Key words: $C O P D$, exacerbation, $\alpha$-1-antitrypsin

\begin{abstract}
Реферат. Хроническая обструктивная болезнь лёгких (ХОБЛ): влияние клинико-анамнестических, антропометрических и функциоальных характеристик на уровень $\alpha-1$-антитрипсина (ААТ) в сыворотке крови стабильных больных. Гашинова Е.Ю. Цель исследования - усовершенствование лечебнодиагностической тактики ведения больных с ХОБЛ на амбулаторном этапе путём изучения уровня ААТ в сыворотке венозной крови. Для окончательного анализа отобраны данные 45 пацичентов с ХОБЛ (GOLD I-IV) и 20 практически здоровых субъектов. Оченивались рост, вес, пол, возраст, индекс массы тела (ИМТ), статус курения. Проводилась спирография, измерялся уровень сывороточного ААТ. Установлено, что у стабильных пацинтов с ХОБЛ и здоровых лии пол, возраст, рост, масса тела, ИМТ, а также стаж заболевания не влияют на уровень ААТ в сыворотке венозной крови. Выявлено сатистически значимое снижение уровня сывороткового ААТ по мере прогрессирования бронхиальной обструкиии у стабильных больных ХОБЛ. Также, $в$ отличие от здоровых лиц, при ХОБЛ стаж курения достоверно негативно связан с уровнем ААТ. Достоверная умеренная негативная корреляция уровня ААТ в сыворотке крови с количеством обострений за прошедший год позволяет предложить оценку данного показателя для прогнозирования течения ХОБЛ у стабильных пациентов.
\end{abstract}

\begin{abstract}
Chronic obstructive pulmonary disease (COPD): influence of clinic-anamnestic, anthropometric and functional characteristics on serum $\boldsymbol{\alpha}$-1-anitrypsin (AAT) in stable patients. Gashynova K. Yu. Aim of the study to enhance the diagnostic and treatment tactics of stable COPD patients management at outpatient stage by studying the serum AAT. Data of 45 outpatients with COPD (GOLD I-IV) and 20 healthy persons were included into analysis. Sex, age, height, weight, body mass index (BMI), smoking status were assessed. Lung function and serum AAT were measured. These results suggest that sex, age, height, weight, BMI do not influence on serum AAT both in stable COPD patients and healthy persons. Serum AAT statistically significant negatively correlate with airways obstruction degree in stable COPD patients. Significant moderate negative correlation between serum AAT and number of exacerbation during last year was found in stable COPD patients. This finding allows to suggest that serum AAT could be used as an indicator for COPD prognosis.
\end{abstract}

Хронічне обструктивне захворювання легень (ХОЗЛ) є надзвичайно актуальною проблемою сучасної пульмонології $[15,18]$. Захворювання дуже часто супроводжується не тільки локальним ураженням дихальних шляхів, а й системними проявами $[2,3,5,6,8,9,10,11,15]$. Сучасна концепція патогенезу ХОЗЛ припускає, що крім ураження бронхів та бронхіол, при цьому недузі виникають деструкція легеневої тканини (хронічна емфізема) та зміни в легеневому судинному руслі $[1,7]$. ААТ є одним 3 найбільш важливих сироваткових інгібіторів протеаз, дефіцит якого призводить до руйнування паренхіми легень [22]. Єдиним доведеним генетично детермінованим чинником розвитку ХОЗЛ $є$ спадковий дефіцит АAТ [18]. За даними різних авторів, він зустрічається в $1-2 \%$ хворих на ХОЗЛ, що в комбінації з тютюнокурінням значною 
мірою може негативно впливати на перебіг захворювання та кінцевий прогноз при ньому $[14,16,17,24]$. Але, на жаль, навіть у ХХІ сторіччі дефіцит ААТ повсюдно залишається дуже рідко діагностованим станом. Так, вважається, що знижений рівень ААТ виявляється лише в 4$4,5 \%$ серед тих, хто, страждаючи на ХОЗЛ та емфізему, має суттєві відхилення від норми цього показника [16, 17, 24]. Такий факт негативно впливає на час початку активної терапії захворювання, i, зрештою, сприяє погіршенню перебігу та прогнозу при ХОЗЛ. У той же час емфізема і при вродженому дефіциті ААТ, і при ХОЗЛ зумовлюється подібними біохімічними процесами. Провідною гіпотезою іiі формування вважається теорія протеазно-антипротеазного дисбалансу [21]. Тому, незалежно від наявності чи відсутності спадкових детермінант недостатності ААТ, логічно припустити, що в будьякому разі однією 3 «цільових груп», які потребують визначення рівня цього ферменту, $\epsilon$ хворі на ХОЗЛ. Питання динаміки рівня ААТ у сироватці крові хворих по мірі прогресування захворювання, а також зв'язок цього показника 3 ризиком майбутніх загострень залишається дуже мало висвітленим у сучасній медичній літературі $[10,11]$. Тому метою цього дослідження було удосконалення лікувально-діагностичної тактики ведення хворих на ХОЗЛ на амбулаторному етапі шляхом вивчення рівня ААТ у сироватці венозної крові стабільних пацієнтів та виявлення факторів, що впливають на його концентрацію.

\section{МАТЕРІАЛИ ТА МЕТОДИ ДОСЛІДЖЕНЬ}

Відповідно до мети, після отримання інформованої згоди було обстежено 65 осіб - 45 амбулаторних хворих на ХОЗЛ у стабільній фазі та 20 практично здорових осіб, які склали контрольну групу. Для уникнення впливу на рівень ААТ сторонніх факторів у остаточний контингент дослідження увійшли лише пацієнти без супутньої патології органів травлення, будь- яких новоутворень, системних захворювань сполученої тканини, коагулопатій, нефротичного синдрому та ознак гострих запальних інфекційних процесів. Усі особи на момент обстеження не мали термічних опіків та не знаходилися в післяопераційному періоді.

У всіх досліджуваних вимірялися антропометричні показники (зріст, вага, стать, вік), розраховувався індекс маси тіла (IMT). Оскільки існують дані про те, що куріння значною мірою впливає на баланс протеазно-антипротеазної системи [23], для всіх індивідів визначався статус куріння (курці, екс-курці, особи, які ніколи не курили) та розраховувався індекс «пачка/рік» («п/р»). Усім особам проводилася спірографія (MasterLab Viasis, Німеччина) та вимірявся рівень ААТ у сироватці крові за допомогою методу кінетичної імунотурбідиметрії з використанням аналізатора Cobas 6000 (с 501 модуль) і тест-систем Roche Diagnostics (Швейцария). У хворих на ХОЗЛ також вивчався вік початку та стаж захворювання, збирався анамнез загострень протягом минулого року, у тому числі й тих, що потребували госпіталізації; проводилося анкетування за шкалою $\mathrm{mMRC}$. На підставі отриманих даних визначалися ступінь та група ХОЗЛ відповідно до міжнародних та вітчизняних рекомендацій $[12,19,20]$.

Отримані результати були оброблені із застосуванням описової та аналітичної статистики за допомогою програми «STATISTICA 6.1» (StatSoft Inc., USA, серійний № AGAR909 E415822FA) [4, 13].

\section{РЕЗУЛЬТАТИ ТА ЇХ ОБГОВОРЕННЯ}

При аналізі основних антропометричних характеристик хворих на ХОЗЛ та здорових осіб встановлено, що переважну $(\mathrm{p}<0,001)$ більшість в обох групах склали чоловіки. До кожної з груп увійшли особи старших вікових категорій. У цілому за основними антропометричними характеристиками хворі на ХОЗЛ були зівставлені зі здоровими індивідами (табл. 1).

Таблиия 1

Загальні характеристики груп порівняння

\begin{tabular}{|c|c|c|c|}
\hline Показники, одиниці вимірювання & $\begin{array}{l}\text { Хворі на ХОЗЛ } \\
\quad(n=45)\end{array}$ & $\begin{array}{l}\text { Здорові } \\
(\mathbf{n}=\mathbf{2 0})\end{array}$ & $\mathbf{p}$ \\
\hline $\begin{array}{l}\text { Стать: } \\
\text { 1) чоловіки, } \mathbf{n}((\mathrm{P} \pm \mathrm{m}) \%) \\
\text { 2) жінки, } \mathbf{n}((\mathrm{P} \pm \mathrm{m}) \%)\end{array}$ & $\begin{array}{c}41(91,1 \pm 4,2) \\
4(8,9 \pm 4,2)\end{array}$ & $\begin{array}{c}18(90,0 \pm 6,7) \\
2(10,0 \pm 6,7)\end{array}$ & $\begin{array}{l}0,606 \\
0,606\end{array}$ \\
\hline Вік, роки Ме [25 \%-75 \%] & $59,0[53,0-62,0]$ & $55,0[52,5-58,0]$ & 0,094 \\
\hline Зріст, см Ме [25 \%-75 \%] & $175,0[170,0-179,0]$ & $176,0[172,5-179,5]$ & $\mathbf{0 , 4 3 7}$ \\
\hline Маса, кг Ме [25 \%-75 \%] & $82,4[71,7-91,0]$ & $80,5[69,5-92,5]$ & $\mathbf{0 , 5 8 2}$ \\
\hline IMT Ме [25\%-75\%], кг/м² & $26,70[24,0-31,7]$ & $25,50[23,3-25,3]$ & 0,845 \\
\hline
\end{tabular}


Також групи порівняння суттєво не відрізнялися за статусом куріння. Переважну $(\mathrm{p}<0,001)$ більшість у кожній 3 них склали колишні або нинішні курці. Стаж куріння («п/р»), хоча й виявився більшим серед хворих на ХОЗЛ, але його відмінності від показника контрольної групи не були статистично значущими (табл. 2).

Таблиия 2

Статус та стаж куріння в групах порівняння

\begin{tabular}{|c|c|c|c|}
\hline Показники, одиниці вимірювання & $\begin{array}{c}\text { Хворі на ХОЗЛ } \\
(\mathrm{n}=45)\end{array}$ & $\begin{array}{l}\text { 3дорові } \\
(\mathbf{n}=\mathbf{2 0})\end{array}$ & $\mathbf{p}$ \\
\hline \multicolumn{4}{|l|}{ Відношення до куріння: } \\
\hline курці, $\mathbf{n}((\mathbf{P} \pm \mathbf{m}) \%)$ & $18(40,0 \pm 7,3)$ & $8(40,0 \pm 11,0)$ & 1,000 \\
\hline екс-курці, $\mathbf{n}((\mathbf{P} \pm \mathbf{m}) \%)$ & $25(55,6 \pm 7,4)$ & $10(50,0 \pm 11,2)$ & 0,678 \\
\hline ніколи не курили, $\mathbf{n}((\mathrm{P} \pm \mathbf{m})$ \%) & $2(4,4 \pm 3,1)$ & $2(10,0 \pm 6,7)$ & 0,390 \\
\hline Індекс «п/р», Ме [25 \%-75 \%] & $50,0[25,0-70,0]$ & $34,5[20,0-50,0]$ & 0,217 \\
\hline
\end{tabular}

Єдиними ознаками, за якими групи порівняння суттєво відрізнялися, як витікає із сутності ХОЗЛ, були показники функції зовнішнього дихання (ФЗД). У хворих на ХОЗЛ об'єм форсованого видиху за першу секунду $\left(\mathrm{OФB}_{1}\right)$ становив 51,0 [34,3-75,9] \%, форсована життєва ємність (ФЖЄЛ) - 89,3 [75,4-99,5] \%, ОФВ 1 ФЖЕЛ дорівнював 43,6[37,2-59,3]\% належних. У контрольній групі ці показники знаходилися в межах норми, складаючи 92,5 [90,3-99,5] \%, $96,8[91,5-100,0] \%, 97,40[93,8-102,7] \%, 89,9[85,4-$ 94,5] \% належних відповідно. Усі вони достовірно ( $p>0,05$ для всіх ознак) перевищували показники хворих на ХОЗЛ.

Рівень задишки за шкалою $\mathrm{mMRC}$ серед пацієнтів з ХОЗЛ суттєво відрізнявся між хворими. Він коливався від 0 до 4 балів. У цілому по групі цей показник становив 2,0 [1,0-2,0] бали.

Серед пацієнтів з ХОЗЛ були представлені особи також 3 різною кількістю загострень протягом минулого року (від 0 до 3). Медіанний та квартильні показники (Ме [25\%-75\%]) у цілому по групі становили 1,0 [0,0-2,0] епізод за рік.

Відповідно до результатів спірографічного дослідження, анкетування за шкалою $\mathrm{mMRC}$, a також враховуючи дані анамнезу загострень протягом минулого року, у всіх хворих на ХОЗЛ була визначена тяжкість обмеження прохідності дихальних шляхів та група захворювання. Встановлено, що 4,4 $3,1 \%$ хворих мала легку

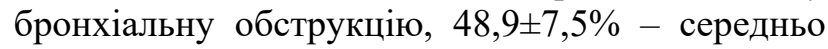

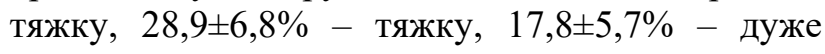
тяжку обструкцію повітроносних шляхів.

Розподіл за групами A, B, C, D дещо відрізнявся від градації відповідно до тяжкості об- меження повітряного потоку. Серед хворих на ХОЗЛ зустрічалися представники усіх груп за класифікацією GOLD, 2011 р. 19 осіб (42,2士7,4\%) були віднесені до груп А та В, тобто малий низький ризик майбутніх загострень, 26 (57,8土7,4\%) до груп C та D, i потенційно належали до категорії 3 високим ризиком погіршення стану в майбутньому.

Медіанні значення ААТ знаходилися в межах норми як в основній, так і в контрольній групі дослідження. Але виявилося, що концентрація ААТ була достовірно ( $<<0,001)$ меншою у хворих на ХОЗЛ (189,5 [147,6-209,2] мг/дл) порівняно зі здоровими особами $(275,0[215,2-310,0]$ мг/дл) (рис. 1).

У здорових учасників дослідження навіть мінімальний показник ААТ (174,5 мг/дл) знаходився в межах референтних значень. У той же час серед пацієнтів з ХОЗЛ у 14 осіб $(31,1 \pm 6,9 \%$ від загальної кількості хворих) рівень ААТ сироватки крові був нижчим, ніж 160 мг/дл, тобто знаходився або на нижній межі нормальних значень (5 осіб - $11,1 \pm 4,7 \%$ хворих), або був нижчим, ніж 150 мг/дл (9 осіб - 20,0 $\pm 6,0 \%$ хворих). Максимальне значення ААТ теж було більшим у здорових осіб.

Не було встановлено суттєвої різниці між рівнем ААТ серед чоловіків та жінок ані у хворих на ХОЗЛ (191,0 [151,1-217,0] мг/дл та 211,7 [175,0$219,0]$ мг/дл відповідно, p=0,562), ані в осіб контрольної групи $(272,6[200,2-345,00]$ мг/дл $\quad$ та $210,3$ [166,0-280,1] мг/дл відповідно, $\mathrm{p}=0,989)$.

Рівень ААТ у сироватці крові достовірно відрізнявся в групах пацієнтів 3 різною тяжкістю обмеження повітряного потоку (табл. 3). 


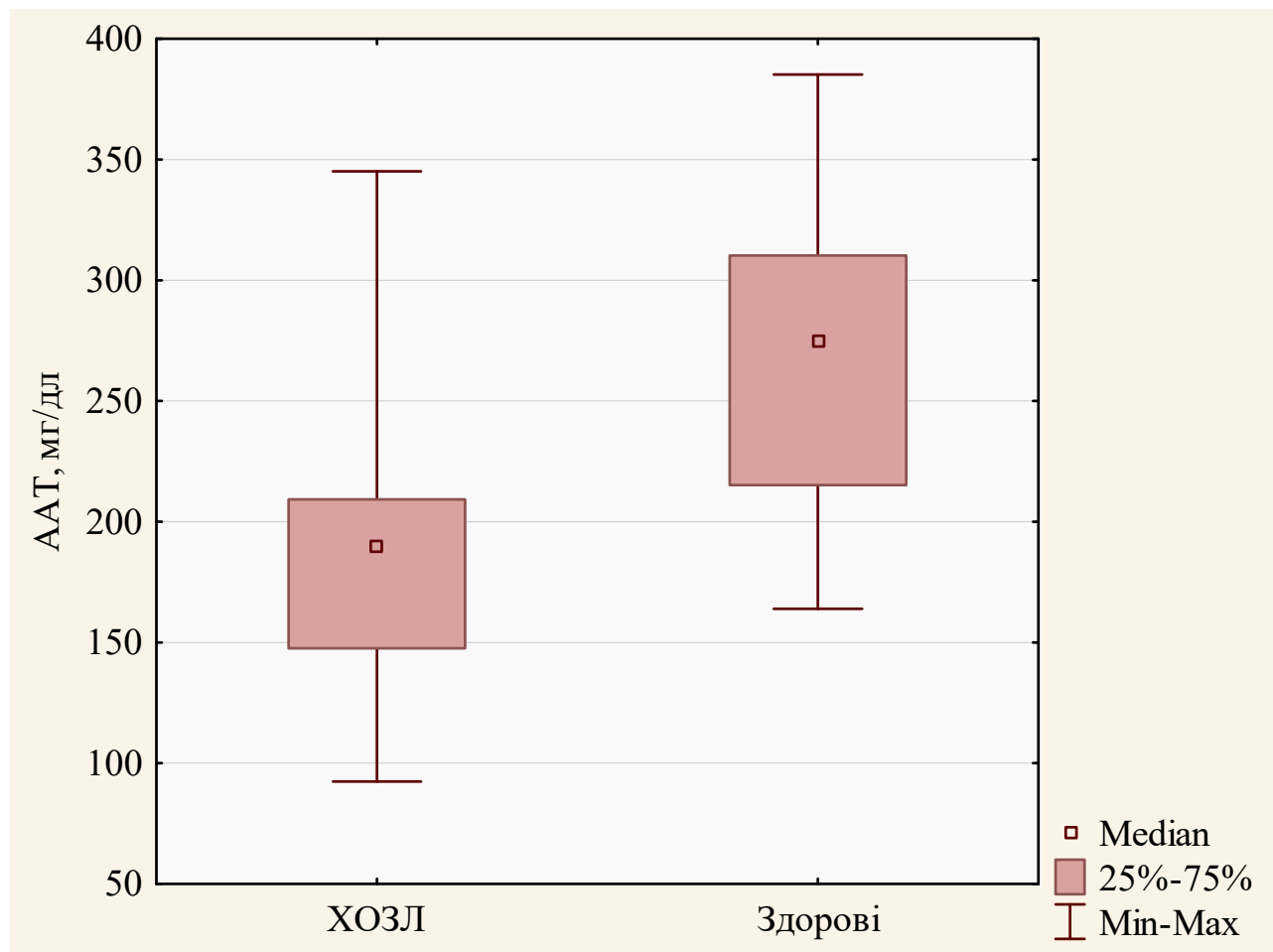

Рис. 1. Рівень ААТ у венозній крові у хворих на ХОЗЛ та здорових осіб

Разом $з$ тим, при попарному порівнянні значення ААТ у пацієнтів 3 легкою обструкцією значуще відрізнялися від осіб з помірним, тяжким та дуже тяжким обмеженням прохідності дихальних шляхів ( $<<0,05$ для всіх). Рівень ААТ у хворих з помірною бронхобструкцією недосто- вірно відрізнявся від такого при тяжкому обмеженні $(p=0,384)$ та достовірно - від показника при дуже тяжкому обмеженні повітряного потоку $(\mathrm{p}=0,007)$. Проте різниця між концентрацією ААТ у хворих на ХОЗЛ III та ХОЗЛ IV не була статистично достовірною $(\mathrm{p}=0,119)$.

\section{Рівень ААТ у сироватці венозної крові в амбулаторних хворих на ХОЗЛ з різним ступенем тяжкості бронхообструкції}

\begin{tabular}{c|c|c}
\hline Ступінь тяжкості бронхообструкції & ААТ, мг/дл Ме [25 \%-75 \%] & $p$ \\
\hline I (легка), $\mathbf{n}=2$ & $242,8[236,0-249,6]$ & 0,009 \\
II (помірна), $n=22$ & $202,9[188,0-214,1]$ \\
III (тяжка), $n=13$ & $164,1[158,4-202,3]$ \\
IV (дуже тяжка), $n=8$ & $146,9[142,3-165,4]$ \\
\hline
\end{tabular}

Хоча найвищі значення ААТ були зареєстровані у хворих 3 мінімальним ризиком загострення і дещо нижчі - серед хворих категорій C та D, відмінності між жодними 3 груп не були статистично достовірними ( $\mathrm{p}=0,232)$. При об'єднанні даних хворих 3 низьким ризиком загострень (А та В) та порівнянні їх з результатами хворих груп
$\mathrm{C}$ i D, хоча достовірних розбіжностей знайдено не було $(\mathrm{p}=0,064)$, але спостерігалася тенденція щодо зниження рівня ААТ при підвищенні ризику загострення ХОЗЛ.

Для визначення можливого взаємозв'язку між рівнем ААТ та деякими антропометричними та клініко-анамнестичними показниками, у тому 
числі й загостреннями захворювання, був проведений кореляційний аналіз. Серед здорових осіб не було встановлено значущого достовірного зв'язку між рівнем сироваткового ААТ та жодною 3 антропометричних ознак $(\mathrm{R}=-0,19$, $\mathrm{p}=0,425$ для зросту, $\mathrm{R}=0,13, \mathrm{p}=0,657$ для загальної маси, $\mathrm{R}=-0,07, \mathrm{p}=0,767$ для віку, $\mathrm{R}=-0,01$, $\mathrm{p}=0,553$ для IMT). Також у контрольній групі вплив стажу куріння на значення сироваткового рівня ААТ був статистично недостовірним $(\mathrm{R}=0,58, \mathrm{p}=0,568)$.

У здорових осіб жоден з показників ФЗД не продемонстрував будь-якої значущої залежності від рівня ААТ у венозній крові $(\mathrm{R}<0,25, \mathrm{p}>0,05$ для всіх ознак).
У хворих на ХОЗЛ усі антропометричні параметри теж не корелювали достовірно 3 показниками ААТ у венозній крові $(\mathrm{R}=-0,28, \mathrm{p}=0,059$ для зросту; $\mathrm{R}=0,21, \mathrm{p}=0,191$ для маси; $\mathrm{R}=0,16$, $\mathrm{p}=, 338$ для IMT; $\mathrm{R}=0,34, \mathrm{p}=0,062$ для віку). Вік початку ХОЗЛ $(\mathrm{R}=0,14, \mathrm{p}=0,406)$ та стаж захворювання на момент обстеження $(\mathrm{R}=0,07$, $\mathrm{p}=0,662$ ) не були пов'язані з показником ААТ у цілому по групі хворих. Проте кількість загострень у минулому році $(\mathrm{R}=-0,54, \mathrm{p}<0,001)$ достовірно помірно негативно корелювала 3 рівнем ААТ у сироватці крові (рис. 2), хоча такий зв'язок не був статистично значущим для загострень, що потребували лікування в стаціонарі $(\mathrm{R}=-0,08, \mathrm{p}=0,626)$.

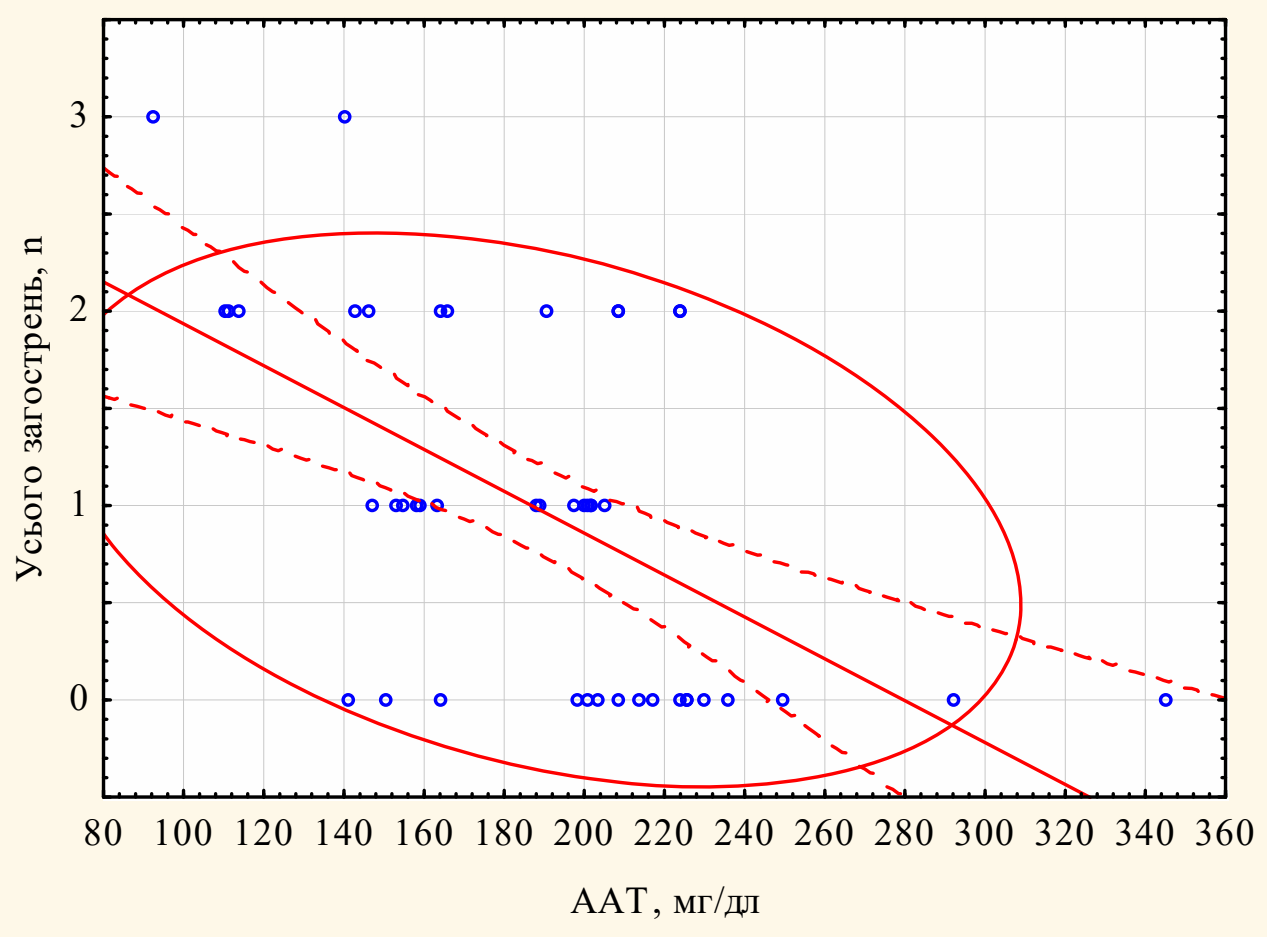

Рис. 2. Зв'язок рівня ААТ у сироватці венозної крові та кількості загострень у минулому році у стабільних амбулаторних хворих на ХОЗЛ

Залежність між рівнем сироваткового ААТ та стажем куріння була помірною $(\mathrm{R}=-0,44)$ та достовірною $(\mathrm{p}=0,003)$. На відміну від здорових осіб, у хворих на ХОЗЛ такий кореляційний зв'язок був негативним. Цей результат підтверджує думку про те, що куріння викликає порушення в легеневій паренхімі лише в певної категорії осіб, а саме, у цьому випадку, у хворих на ХОЗЛ, порушуючи в них баланс протеазноантипротеазної системи.

У хворих на ХОЗЛ виразність задишки не була пов'язаною 3 рівнем $\mathrm{AAT}(\mathrm{R}=-0,26$, $\mathrm{p}=0,086)$. Спостерігалося статистично значуще зниження сироваткового рівня ААТ по мірі прогресування бронхіальної обструкції $(\mathrm{R}=-0,42$, $\mathrm{p}=0,004)$ (рис. 3).

Значення ААТ у венозній крові не залежали достовірно від групи ризику розвитку загострення $(\mathrm{R}=-0,18, \mathrm{p}=0,248)$. Протилежний результат спостерігався при вивченні у хворих на ХОЗЛ взаємовідношення між ОФВ 1 та рівнем сироваткового АAТ $(\mathrm{R}=0,42, \mathrm{p}=0,006)$ (рис. 4). 


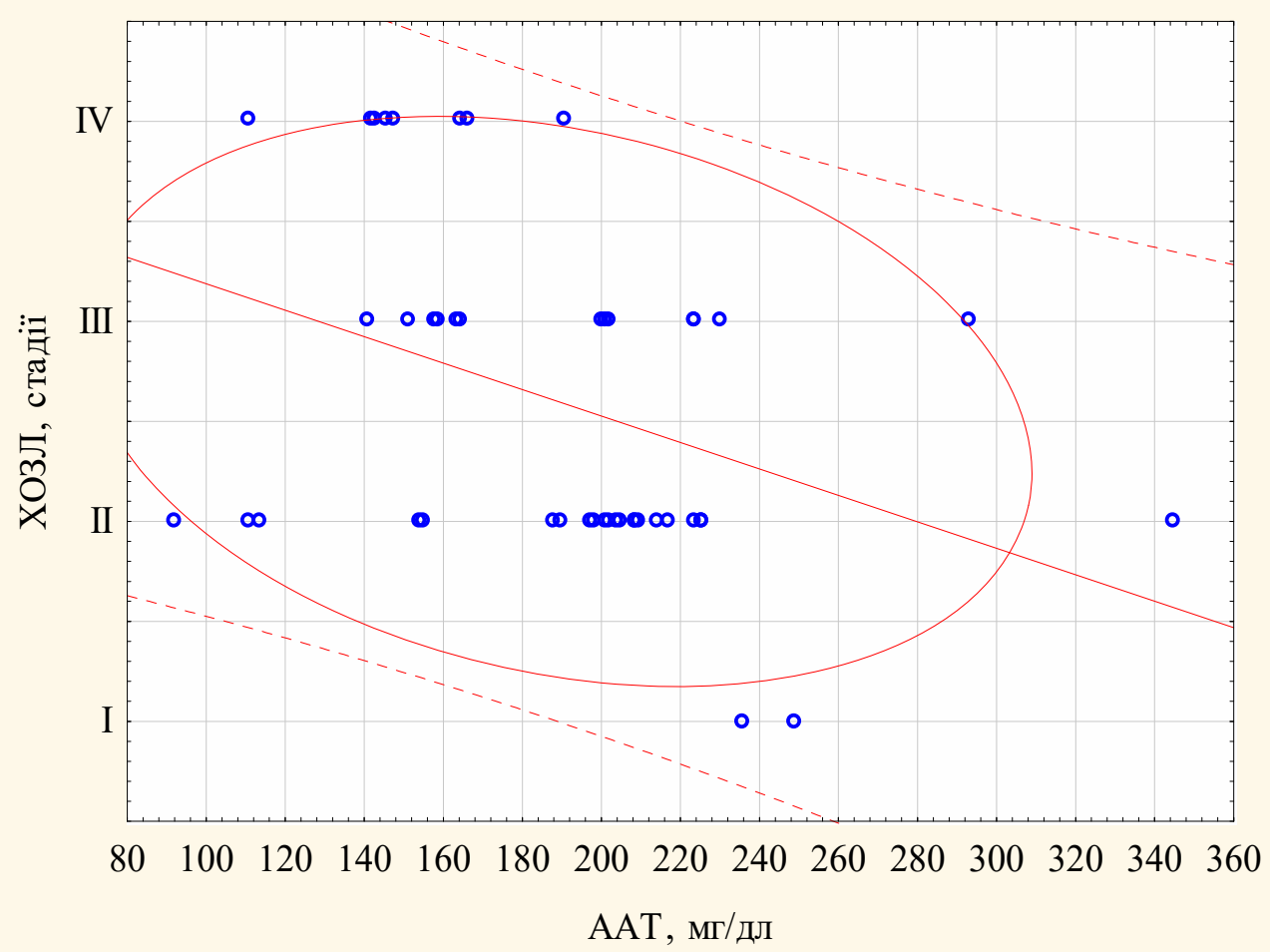

Рис. 3. Зв'язок рівня ААТ у венозної крові та ступеня бронхообструкції в стабільних хворих на ХОЗЛ

Проте кореляція рівня ААТ 3 іншими показниками ФЗД (ФЖЕЛ, ОФВ 1 /ФЖЕЛ) не була значущою та достовірною ( $>0,05$ для всіх інших показників, що вивчалися). Подібні результати вельми відрізнялися від даних кореляційного аналізу між показниками ФЗД та рівнем ААТ у здорових осіб, що підтверджує припущення про зв'язок між низьким рівнем ААТ та порушенням функціональних характеристик органів дихання лише в певної когорти індивідів. На нашу думку, подальше вивчення цієї проблеми дуже доцільне і заслуговує ретельної уваги.

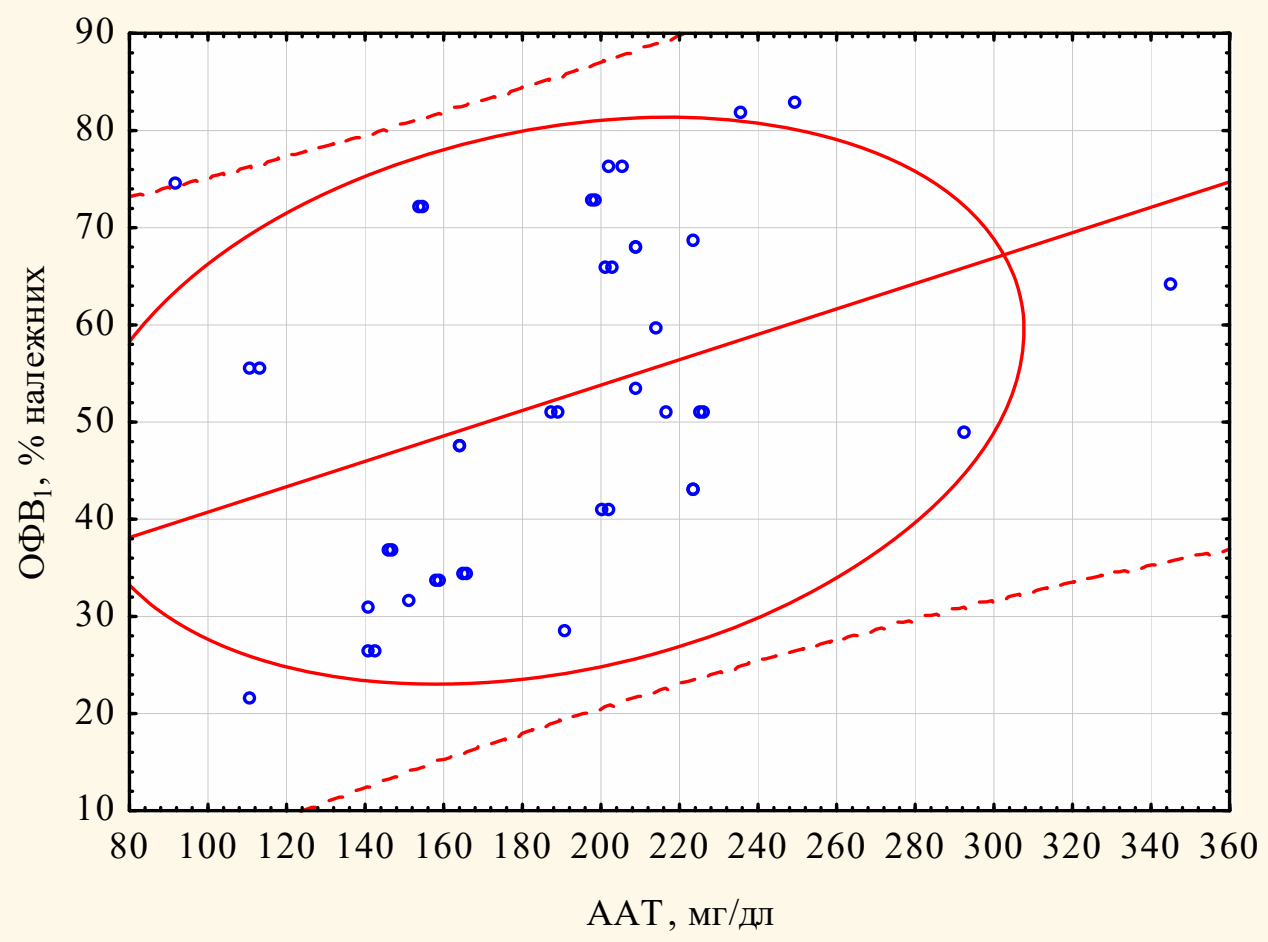

Рис. 4. Зв'язок рівня ААТ у сироватці венозної крові та ОФВ 1 у стабільних амбулаторних хворих на ХОЗЛ 


\section{ВИСНОВКИ}

1. У стабільних хворих на ХОЗЛ та в здорових осіб ані стать, ані вік, ані зріст, ані маса тіла та IMT не впливають на рівень ААТ у сироватці венозної крові.

2. Незважаючи на те, що виразність задишки не пов'язана $з$ рівнем ААТ, встановлене статистично значуще зниження сироваткового рівня ААТ по мірі прогресування бронхіальної обструкції в стабільних хворих на ХОЗЛ.

3. На відміну від здорових осіб, негативна залежність між рівнем сироваткового ААТ та стажем куріння у хворих на ХОЗЛ була достовірною.

4. Вік початку ХОЗЛ та стаж захворювання на момент обстеження не були пов'язані 3 показником ААТ.

5. Достовірна помірна негативна кореляція рівня ААТ у сироватці крові 3 кількістю загострень у минулому році дозволяє запропонувати вимірювання цього показника для прогнозування перебігу ХОЗЛ у стабільних хворих.

\section{СПИСОК ЛІТЕРАТУРИ}

1. Аверьянов А.В. Роль нейтрофильной эластазы в патогенезе хронической обструктивной болезни легких / А. В. Аверьянов // Цитокины и воспаление. 2007. - № 4. - С. 3-8.

2. Коваленко О.М. Особливості тромбоцитарної ланки гемостазу у хворих з хронічним обструктивним захворюванням легенів у сполученні з гіпертонічною хворобою / О.М. Коваленко, В.В. Родіонова, Н.О. Вороніна // Медичні перспективи. - 2017. -№ 3. - С. 28-33.

3. Кононович О.С Инфекционное обострение хронического обструктивного заболевания легких: особенности спектра возбудителей в регионе Приднепровья / О.С. Кононович, О.В. Плеханова, В.В. Дмитриченко // Укр. пульмонол. журн. - 2008. № 3. - С. 181-182.

4. Лапач С.Н. Статистические методы в медикобиологических исследованиях с использованием Exel / С.Н. Лапач, А.В. Губенко, П.Н. Бабич. - Киев: Морион, 2000. - 320 с.

5. Мостовой Ю.М. ХОЗЛ. Системные эффекты и их профилактика / Ю.М. Мостовой, А.В. Демчук // Укр. пульмонол. журнал. - 2011. - № 2. - С. 22-23.

6. Островський М.М. До питання поліморбідності та коморбідності у хворих на ХОЗЛ / М.М. Островський, П.Р. Герич // Укр. пульмонол. журн. 2011. - № 4. - С. 19-24.

7. Перцева Т.А. Оценка состояния мукоцилиарного клиренса у пациентов с хроническим обструктивным заболеванием лёгких / Т.А. Перцева, Е.А. Лихолат, Е.В. Гуржий // Укр. пульмонол. журнал. - 2007. - № 3.- С. 16-18.

8. Перцева Т.А. Оценка функционального состояния дыхательной мускулатуры у больных хроническими обструктивными заболеваниями легких в формировании индивидуальных программ реабилитации / Т.А. Перцева, Л.И. Конопкина, Е.В. Богуславская // Укр. пульмонол. журн. - 2004. - № 3. - С. 31-32.

9. Перцева Т.О. Особливості перебігу порушень серцевого ритму та провідності у хворих із поєднанням ішемічної хвороби серця, артеріальної гіпертензії та хронічного обструктивного захворювання легень / Т.О. Перцева, О.В. Фесенко // Медичні перспективи. - 2009. - Т. XIV, № 3. - С. 28-33.
10. Перцева Т.О. Рівень $\alpha 1$-антитрипсину (ААТ) у хворих на хронічне обструктивне захворювання легень / Т.О. Перцева, К.Ю. Гашинова, Ю.І. Вікліснко // Медичні перспективи. - 2011. - Т. XVI, № 2. - С. 98-104.

11. Перцева Т.О. ХОЗЛ: рівень ААТ у сироватці крові та частота загострень захворювання / Т.О. Перцева, К.Ю. Гашинова, Ю.І. Віклієнко // Медичні перспективи. - 2011. - Т. XVI, № 4. - С. 21-24.

12. Про затвердження та впровадження медикотехнологічних документів зі стандартизації медичної допомоги при хронічному обструктивному захворюванні легень: Наказ МО3 України № 555 від 27.06.2013. - Київ, 2013. - 3 с.

13. Реброва О.Ю. Статистический анализ медицинских данных. Применение пакета прикладных программ STATISTICA / O.Ю. Реброва. - Москва: Медиасфера, 2002. - 312 с.

14. Рекомендации по диагностике и ведению больных с дефицитом $\alpha 1$-антитрипсина Испанского общества пульмонологии и торакальной хирургии / Р. Видаль [и др.] // Пульмонология. - 2008. - № 1. C. $14-28$.

15. Фещенко Ю.И. ХОЗЛ в Украине: проблемы и пути решения [Електронный ресурс] / Ю. И. Фещенко // Здоров'я України. - 27.03.2015. - Режим доступу: http://health-ua.com/article/3876.html

16. Chapman H.A. Protease injury in the development of COPD [Text] / Harold A. Chapman Jr., Guo-Ping Shi // Chest. - 2000. - Vol. 117. - P. 295S-299S.

17. DeMeo D.L. Alpha1-antitrypsin deficiency. Genetic aspects of alpha1-antitrypsin deficiency: phenotypes and genetic modifiers of emphysema risk / D.L. DeMeo, E.K. Silverman // Thorax. - 2004. - Vol. 59. - P. 259-264.

18. Global Initiative for Chronic Obstructive Lung Diseases (GOLD). Global strategy for diagnosis, management, and prevention of chronic obstructive pulmonary disease [Electronic Resource] / Updated 2016. - Available at: http:/goldcopd.org/global-strategy-diagnosismanagement-prevention-copd-2016/

19. Global Initiative for Chronic Obstructive Lung Diseases (GOLD). Global strategy for diagnosis, management, and prevention of chronic obstructive pulmonary disease [Electronic Resource] / Revised, 2011. - Avai- 
lable at: http://www.goldcopd.org/uploads/users/files/GOLD_Report_2011_Feb21.pdf

20. Global Initiative for Chronic Obstructive Lung Diseases (GOLD). Global strategy for diagnosis, management, and prevention of chronic obstructive pulmonary disease [Electronic Resource] / GOLD, 2013. - Availableat: http://www.goldcopd.it/gruppi_lavoro/2013/GOLD\%20EXECUTIVE\%20SUMMARY.pdf

21. Laurell C.B. The electrophoretic $\alpha 1$-globulin pattern of serum in $\alpha 1$-antitrypsin deficiency / C.B. Laurell, S. Eriksson // Scan. J. Clin. Lab. Invest. - 1963. Vol. 15. - P. 132-140.
22. Stoller J. Clinical manifestations, diagnosis, and natural history of alpha-1 antitrypsin deficiency / J.K. Stoller, P.J. Barnes, H. Hollingsworth // Available at: http://www.uptodate.com/contents/topic.do?topicKey=PULM/1464\#

23. Survival and FEV1 decline in individuals with severe deficiency of $\alpha 1$-antitrypsin. The alpha-1-antitrypsin deficiency registry study group / Am. J. Respir. Crit. Care Med. - 1998. - Vol. 158, N 1. - P. 49-59.

24. Vidal R. Standards for the Diagnosis and Management of Individuals with Alpha-1 Antitrypsin Deficiency / R. Vidal // Am. J. Resp. Critic. Care Med. 2003. - Vol. 168. - P. 818-900.

\section{REFERENCES}

1. Averyanov AV. [The role of neutrophil elastase in the pathogenesis of chronic obstructive pulmonary disease]. Tsitokinyi i vospalenie. 2007;4:3-8. Russian.

2. Kovalenko OM, RodIonova VV, Voronina NO. [Features of thrombocyte linkage of hemostasis in patients with chronic obstructive pulmonary disease in combination with hypertension]. Medicni perspektivi. 2017;3:28-33. Ukainian.

3. Kononovich OS, Plehanova OV, Dmytrychenko VV, Bratus EV. [Infectious exacerbation of chronic obstructive pulmonary disease: features of the spectrum of pathogens in the Pridneprovia region] Ukr. pulmonol. zhurn. 2008;3:181-182. Russian.

4. Lapach CN, Gubenko AV, Babich PN. [Statistical methods in biomedical research using Excel]. Kyiv, Morion. 2000;320. Russian.

5. Mostovoy YuM, Demchuk AV. [COPD. Systemic effects and their prevention]. Ukr. pulmonol. zhurn. 2011;2:22-23. Russian.

6. Ostrovskiy MM, Gerich PR. [On the issue of polymorbidity and comorbidity in patients with COPD] Ukr. pulmonol. zhurn. 2011;4:19-24. Ukainian.

7. Pertseva TA, Liholat EA, Gurzhiy EV. [Assessment of mucociliary clearance in patients with chronic obstructive pulmonary disease]. Ukr. pulmonol. zhurn. 2007;3:16-18. Russian.

8. Pertseva TA, Konopkina LI, Boguslavskaya EV. [Assessment of the functional state of respiratory muscles in patients with chronic obstructive pulmonary diseases in the formation of individual rehabilitation programs]. Ukr. pulmonol. zhurn. 2004;3:31-32. Russian.

9. Pertseva TO, Fesenko OV. [Peculiarities of the course of violations of cardiac rhythm and conduction in patients with a combination of coronary heart disease, arterial hypertension and chronic obstructive pulmonary disease]. Medicni perspektivi. 2009; XIV(3):28-33. Ukrainian.

10. Pertseva TO, Gashynova KYu, Viklienko YuI. [ $\alpha 1$-antitrypsin (AAT) level in patients with chronic obstructive pulmonary disease]. Medicni perspektivi. 2011;XVI(2):98-104. Ukainian.

11. Pertseva TO, Gashynova KYu, Viklienko YuI. [COPD: $\alpha 1$-antitrypsin (AAT) level and exacerbation frequency]. Medicni perspektivi. 2011;XVI(4):21-24. Ukainian.
12. [On approval and implementation of medicaltechnological documents on standardization of medical care in chronic obstructive pulmonary disease: Order of the Ministry of Health of Ukraine No. 555 dated June 27, 2013]. Kyiv, Official publication. 2013;3. Ukainian.

13. Rebrova OYu. [Statistical analysis of medical data. Application of the STATISTICA application package]. Moskva, Mediasphera. 2002;312. Russian.

14. Vida $\mathrm{R}$ et al. [Recommendations for the diagnosis and management of patients with a deficiency of $\alpha 1$ antitrypsin in the Spanish Society of Pulmonology and Thoracic Surgery]. Pulmonologia. 2008;1:14-28. Russian.

15. Feschenko YuI. [COPD in Ukraine: problems and solutions]. Zdorov'ya Ukrainy. 27.03.2015. Available from: http://health-ua.com/article/3876.html. Russian.

16. Chapman H, Shi G. Protease Injury in the Development of COPD. Chest. 2000;117(5):295S-8S.

17. DeMeo D. Alpha1-Antitrypsin deficiency: Genetic aspects of Alpha1-antitrypsin deficiency: phenotypes and genetic modifiers of emphysema risk. Thorax. 2004;59(3):259-64

18. Global Initiative for Chronic Obstructive Lung Diseases (GOLD). Global strategy for diagnosis, management, and prevention of chronic obstructive pulmonary disease. [Internet]. Updated 2016. Available from: http://goldcopd.org/global-strategy-diagnosis-management-prevention-copd-2016.

19. Global Initiative for Chronic Obstructive Lung Diseases (GOLD). Global strategy for diagnosis, management, and prevention of chronic obstructive pulmonary disease. [Internet]. Revised; 2011. Available from: http://www.goldcopd.org/uploads/users/files/GOLD_Rep ort 2011_Feb21.pdf.

20. Global Initiative for Chronic Obstructive Lung Diseases (GOLD). Global strategy for diagnosis, management, and prevention of chronic obstructive pulmonary disease. [Internet]. GOLD; 2013. Available from: http://www.goldcopd.it/gruppi_lavoro/2013/GOLD\%20E XECUTIVE\%20SUMMARY.pdf.

21. Laurell C, Eriksson S. The Electrophoretic $\alpha ; 1-$ Globulin Pattern of Serum in $\alpha ; 1$-Antitrypsin Deficiency. Scandinavian Journal of Clinical and Laboratory Investigation. 1963;15(2):132-40.

22. Stoller J. Clinical Features and Natural History of Severe $\alpha 1$-Antitrypsin Deficiency. Chest. 1997;111(6):123-8. 
23. Survival and FEV1Decline in Individuals with Severe Deficiency of $\alpha 1$-Antitrypsin. American Journal of Respiratory and Critical Care Medicine. 1998;158(1):49-59.
24. Vidal R. American Thoracic Society/European Respiratory Society Statement. American Journal of Respiratory and Critical Care Medicine. 2003;168(7):818-900.

\author{
Л.А. Глиняна ${ }^{1}$, \\ B.В. Родіонова ${ }^{2}$, \\ К.Ю. Гашинова ${ }^{2}$, \\ К.О. Чебанов ${ }^{1}$, \\ H.O. Буm ${ }^{1}$, \\ O.I. Біла ${ }^{3}$, \\ T.A. Мазурецьв ${ }^{3}$
}

\title{
СТРУКТУРА ПРОМИСЛОВО ЗУМОВЛЕНИХ ЗАХВОРЮВАНЬ У РОБІТНИКІВ МЕТАЛУРГІЙНОГО ПІДПРИЕМСТВА, ЯКІ ПРАЦЮЮЮТЬ У ШКІДЛИВИХ УМОВАХ
}

Міський центр лікування професійних захворювань

КЗ «Дніпропетровська міська багатопрофільна клінічна лікарня № 4» ДОР» ${ }^{1}$

вул. Ближня, 31, Дніпро, 49101, Україна

ДЗ «Дніпропетровська медична академія МОЗ України» ${ }^{2}$

кафедра професійних хвороб та клінічної імунології

вул. В. Вернадського, 9, Дніпро, 49044, Україна

Головне управління Держпрачі у Дніпропетровській області ${ }^{3}$

вул. Казакова, 3, Дніпро, 49107, Україна

Center for treatment of occupational diseases of the

$M I$ "Dnipropetrovsk city multiprofile clinical hospital $N 4^{\prime \prime} D R C^{\prime \prime}$

Blyzhnia str., 31, Dnipro, 49101, Ukraine

$S E$ «Dnipropetrovsk medical academy of Health Ministry of Ukraine» ${ }^{2}$

Department of Occupational Diseases and Clinical Immunology

V. Vernadsky str., 9, Dnipro, 49044, Ukraine

Main Department of State Labor in Dnipropetrovsk Region ${ }^{3}$

Kazakova str., 3, Dnipro, 49107, Ukraine

e-mail: korica.list@gmail.com

Ключові слова: металургійне підприємство, промислово зумовлені захворювання, медичні огляди, прачююче населення, реабілітація.

Ключевые слова: металлургическое предприятие, производственно обусловленные заболевания, медицинские осмотры, работающее население, реабилитация

Key words: metallurgical enterprise, industrially determined diseases, medical examinations, working population, rehabilitation

Реферат. Структура промышленно обусловленных заболеваний у рабочих металлургического предприятия, работающих во вредных условиях. Глиняная Л.А., Родионова В.В., Гашинова Е.Ю., Чебанов К.О., Бут Н.А., Белая Е.И., Мазурец Т.А. Проведен анализ результатов медицинского осмотра с определением состояния здоровья 783 работников металлургического предприятия в городе Днепр, из них 295 женщин

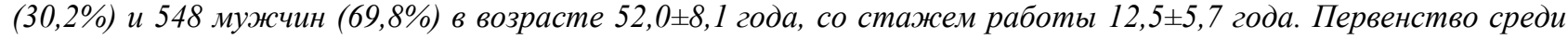
заболеваний занимают заболевания сердечно-сосудистой системы, далее следуют заболевания верхних дыхательных путей, сосудов нижних конечностей, опорно-двигательного аппарата и сенсо-невральная тугоухость. Выявленная патология чаще встречается у мужчин отдельных профессий.

Abstract. The structure of industrially predisposed diseases in workers of the metallurgical enterprise working in harmful conditions. Hlyniana L.A., Rodionova V.V., Gashynova K.Y., Tchebanov K.O., But N.A., Bila E.I., Masurez T.A. The analysis of the medical examination results with the evaluation of health status was conducted in 783 employees of the metallurgical enterprise in Dnipro city, The data of 295 women (30,2\%) and 548 men (69,8\%), 